\title{
Peningkatan Partisipasi Belajar Siswa Kelas VI Pada Pembelajaran PKn Dengan Menggunakan Model Guided Teaching Di SDN 17 Batang Anai Kabupaten Padang Pariaman
}

\section{Eva Wardanis}

\begin{abstract}
This research is based on the lack of student's participation in learning PKn subject. This research is aimed to improve the participation in learning of students grade VI SDN 17 Batang Anai by implementing guided teaching model. This is a class action research that consists of two cycles including four steps: planning, action, observation, and reflection. Data of research were obtained through observation sheets, and test. Obtained data were analyzed quantitatively and qualitatively. Percentage of student's participation in proposing ideas is $30 \%$ in cycle I and become $77.5 \%$ in cycle II. Meanwhile, percentage of student's participation in answering questions is $40 \%$ in cycle I and become $85 \%$ in cycle II. Percentage of student's participation in proposing questions is $17.5 \%$ in cycle I and become $70 \%$ in cycle II. Hence, it can be concluded that guided teaching model can improve participation in learning PKn subject of students grade VI SDN 17 Batang Anai Kabupaten Padang Pariaman.
\end{abstract}

Keyword: participation in learning, guided teaching

Copyright (C) 2016 IICET (Padang - Indonesia) - All Rights Reserved Indonesian Institute for Counseling, Education and Theraphy (IICET)

\section{PENDAHULUAN}

Untuk meningkatkan kualitas pendidikan pemerintah Indonesia melalui Kementrian Pendidikan dan Kebudayaan berusaha dengan berbagai cara seperti: merevisi kurikulum, meningkatkan kualitas guru, perbaikan proses pembelajaran, dan sebagainya. Hal ini dilakukan agar melahirkan manusia yang berkualitas. Manusia yang berkualitas dapat terwujud salah satunya dengan mengikuti pendidikan dan pendidikan formal yang kedua yang akan dimasuki oleh anak adalah pendidikan sekolah dasar (SD) setelah Taman KanakKanak. PKn merupakan salah satu mata pelajaran yang diajarkan di SD. Pembelajaran PKn lebih menekankan kepada pembentukan sikap yang bertujuan agar peserta didik lebih memiliki pengetahuan dan kemampuan untuk menjadi warga negara yang baik, serta memiliki kepribadian yang sesuai dengan Pancasila sebagai falsafah hidup bangsa Indonesia.

Pembelajaran PKn diupayakan agar dapat mempersiapkan siswa memiliki kepribadian yang mantap. PKn membantu siswa agar memiliki sikap menghormati dan tenggang rasa terhadap sesama, Pembelajaran PKn akan dapat dipahami dan nilai-nilai yang diperoleh dari PKn dapat diamalkan dalam kehidupan oleh siswa, maka peran guru sangat dituntut untuk dapat menciptakan proses pembelajaran yang menyenangkan, bermakna, menantang, serta dapat mengaktifkan belajar siswa. Untuk mewujudkan tujuan pembelajaran PKN tersebut diperlukan model pembelajaran yang relevan, salah satunya mengunakan model pembelajaran Guided Teaching, penggunaan model pembelajaran dalam proses pembelajaran mempunyai arti yang cukup penting. Model pembelajaran membantu siswa untuk memahami pembelajaran dengan mudah. Dengan menggunakan model pembelajaran Guided Teaching dalam proses pembelajaran, akan dapat menghilangkan rasa jenuh siswa terhadap pembelajaran PKN SD.

Mengingat pentingnya model pembelajaran, seorang guru dituntut mampu memilih dan menggunakan model pembelajaran yang baik. Hal ini berguna untuk dapat meningkatkan partisipasi siswa dalam proses pembelajaran PKN SD. Partisipasi belajar merupakan sebagai alat ukur keterlibatan anggota dalam melakukan berbagai aktivitas. Menurut Tannenbaun dan Hahn(dalam Tukiran Taniredja, 2010:96), " partisipasi merupakan suatu tingkat sejauh mana peran anggota melibatkan diri dalam kegiatan dan menyumbangkan tenaga dan pikiranya dalam pelaksanaan kegiatan tersebut". Selanjutnya Dusseldor (dalam Tukiran Taniredja, 2010:96), "patisipasi diartikan sebagai kegiatan atau keadaan mengambil bagian dalam suatu aktivitas untuk mencapai kemanfaatan optimal". Jadi partisipasi belajar adalah keterlibatan dalam melakukan berbagai aktivitas melalui kegiatan pembelajaran untuk mencapai hasil yang optimal

Berdasarkan pengalaman peneliti pada pembelajaran PKN bahwa proses pembelajaran selama ini masih terpusat pada guru, sedangkan siswa hanya menulis apa yang disampaikan oleh guru, sehingga tidak 
tampak partisipasi dari siswa. Selama proses pembelajaran PKN, peneliti juga melihat kurangnya keinginan siswa untuk bertanya sedangkan mereka belum memahami materi yang diajarkan guru, kurangnya siswa menjawab pertanyaan yang diberikan guru, maupun mengemukakan pendapat pada guru. Pendekatan yang dilakukan guru cenderung menggunakan pendekataan yang konvensional. Pada pendekataan konvensional ini guru menjelaskan materi pelajaran terlebih dahulu, setelah itu siswa disuruh untuk mencatat. Akibatnya siswa menjadi bosan karena tidak menemukan sesuatu yang baru dalam pembelajaran.

Selain itu, jika dilihat dari hasil ujian semester siswa juga masih belum mencapai Kriteria Ketuntasan Minimal (KKM) 70 dan ada beberapa orang siswa yang belum mencapai KKM. Rendahnya nilai siswa di antaranya disebabkan oleh kurang tepatnya metode yang digunakan oleh guru, juga ketidaktersediaan sumber belajar. Seperti terlihat dari rerata nilai ujian semester I siswa kelas VI SD negeri 17 Batang Anai adalah 65, dimana siswa yang mendapatkan nilai di atas KKM adalah 7 orang (35\%) mendapat nilai 70 ke atas dan yang berada di bawah KKM sebanyak 13 orang (65\%) mendapat nilai 69 kebawah. Nilai tertinggi diperoleh oleh siswa adalah 90 dan nilai terendah yang diperoleh oleh siswa adalah 40. Kriteria Ketuntasan Minimal (KKM) yang ditetapkan oleh sekolah tersebut khususnya untuk mata pelajaran PKN adalah 70. Dari pernyataan di atas dapat disimpulkan bahwa masih banyak siswa yang mendapatkan nilai di bawah rata-rata Kriteria Ketuntasan Minimal (KKM) .

Menurut peneliti, hal ini terjadi karena ketidaktahuan siswa dengan tujuan pembelajaran dan kurang tertariknya siswa dengan apa yang disampaikan guru di kelas, berdasarkan hasil wawancara peneliti dengan kepala sekolah, diketahui bahwa rendahnya hasil belajar siswa disebabkan karena rendahnya partisipasi mengemukakan pendapat siswa, rendahnya partisipasi siswa menjawab soal, kurangnya partisipasi siswa untuk bertanya, dan seringnya tugas yang diberikan oleh guru tidak diselesaikan oleh siswa. Hal itu diperparah oleh sarana dan prasarana yang kurang memadai. Rendahnya partisipasi siswa dalam pembelajaran tidak dapat dibiarkan, dan karena itu diperlukan suatu upaya untuk menumbuhkan partisipasi belajar siswa. Di sini, peneliti menetapkan solusi terhadap masalah tersebut, dengan menerapkan Model Pembelajaran Guided Teaching.

Guided Teaching merupakan rangkaian penyampaian materi ajar yang diawali dari suatu pertanyaan yang dijadikan dasar untuk menyampaikan materi berikutnya (Istarani, 2012:256). Menurut Silberman (2009:163) "Salah satu model pembelajaran aktif yaitu Guided Teaching. Guided Teaching merupakan model pembelajaran yang meningkatkan kemampuan tanggung jawab peserta didik terhadap apa yang mereka pelajari melalui cara yang menyenangkan dan tidak menakutkan bagi siswa tersebut". Menurut Zaini (2005:37) dalam model ini, guru bertanya kepada siswa satu atau dua pertanyaan untuk mengetahui tingkat pemahaman siswa atau untuk memperoleh hipotesi atau kesimpulan kemudian membaginya kepada kategori. Menurut Istarani (2012:227) kelebihan model pembelajaran Guided Teaching yaitu: (1) Dapat meningkatkan motivasi belajar siswa sebab pembelajaran diawali dengan pertanyaan; (2) Melatih siswa berfikir untuk menjawab pertanyaan secara benar; dan (3) Dapat meningkatkan kerjasama siswa karena dalam belajar dibentuk kelompok-kelompok kecil.

Berdasarkan uraian di atas, maka peneliti melakukan penelitian tindakan kelas untuk meningkatkan partisipasi belajar siswa kelas VI SDN 17 Batang Anai Kabupaten Padang Pariaman melalui implementasi model guided teaching dalam pembelajaran PKn. Tujuan penelitian ini meliputi: (1) Mendeskripsikan peningkatan partisipasi belajar siswa kelas VI dalam mengemukakan pendapat pada pembelajaran PKN dengan Model Pembelajaran Guided Teaching di SD Negeri 17 Batang Anai Kabupaten Padang Pariaman; (2) Mendeskripsikan peningkatan partisipasi belajar siswa kelas VI dalam menjawab pertanyaan pada pembelajaran PKN dengan Model Pembelajaran Guided Teaching di SD Negeri 17 Batang Anai Kabupaten Padang Pariaman; dan (3) Mendeskripsikan peningkatan partisipasi belajar siswa kelas VI dalam mengajukan pertanyaan pada pembelajaran PKN dengan Model Pembelajaran Guided Teaching di SD Negeri 17 Batang Anai Kabupaten Padang Pariaman.

\section{METODOLOGI PENELITIAN}

Penelitian ini akan dilaksanakan di SDN 17 Batang Anai Kabupaten Padang Pariaman. SD ini terletak di dusun Kali Air Kanagarian Sungai Buluah Kecamatan Batang Anai. Alasan peneliti memilih sekolah ini sebagai tempat penelitian, dengan pertimbangannya: Pertama, proses pembelajaran masih berpusat pada guru dan guru mengajar dengan teknik pembelajaran yang menoton sehingga siswa sulit memahami materi yang disampaikan oleh guru. Kedua, siswa hanya menganggap pelajaran PKN ini sebagai pelajaran yang membosankan. Ketiga sekolah bersedia untuk menerima pembaharuan pendidikan dalam proses pembelajaran. Keempat sekolah ini tempat peneliti bertugas. Sebagai subjek dalam penelitian ini adalah siswa kelas VI SD Negeri 17 Batang Anai, yang mana jumlah siswanya 20 orang, yang terdiri dari laki-laki berjumlah 12 orang $(60 \%)$ dan perempuan berjumlah 8 orang $(40 \%)$. Jenis penelitian ini adalah penelitian 
tindakan kelas yang meliputi tahap perencanaan, pelaksanaan, pengamatan, dan refleksi. Data penelitian diperoleh melalui observasi dan tes. Data yang diperoleh kemudian dianalisis dengan menggunakan pendekatan kualitatif dan kuatitatif karena peneliti ingin mengamati fenomena yang terjadi di dalam kelas.

\section{HASIL DAN PEMBAHASAN PENELITIAN}

\section{A. Hasil Penelitian}

1. Siklus I

a) Tahap Perencanaan

Sebelum menerapkan tindakan pada siklus I, guru melihat terlebih dahulu kondisi pembelajaran PKN pada siswa kelas VI SD Negeri 17 Batang Anai. Tindakan ini digunakan untuk melihat kondisi awal, sehingga dapat dijadikan patokan terhadap adanya peningkatan partisipasi belajar siswa setelah dilakukan tindakan. Sebelum penelitian dilaksanakan, terlebih dahulu peneliti menyiapkan rencana pelaksanaan pelajaran (RPP), lembar observasi belajar siswa, lembar aktifitas guru, soal latihan dan lembar jawaban yang sesuai dengan model yang dipakai peneliti.

\section{b) Tahap Pelaksanaan}

Pelaksanaan pembelajaran pada siklus I dilakukan dalam dua kali pertemuan. Proses pembelajaran terdiri atas kegiatan pembukaan, kegiatan inti, dan kegiatan penutup.

\section{c) Tahap Pengamatan}

Pengamatan dilakukan untuk setiap kali pertemuan, oleh observer dan observer mengisi lembar observasi partisipasi belajar siswa, lembar observasi aktivitas guru dalam pembelajaran PKN melalui Model pembelajaran Guided Teaching Pada akhir siklus diberikan tes hasil belajar berupa soal tes. Hasil pengamatan observer terhadap partisipasi belajar siswa dan aktivitas guru, menunjukan bahwa pembelajaran yang dilakukan guru sudah baik, namun belum semua indikator keberhasilan yang tercapai dalam pembelajaran. Untuk lebih jelasnya, hasil pengamatan observer terhadap partisipasi belajar siswa, aktivitas guru, dan tes berupa soal tes diuraikan sebagai berikut:

1) Data Hasil Observasi Partisipasi Belajar Siswa

Data hasil observasi ini didapat melalui lembar observasi partisipasi belajar siswa, dan digunakan untuk melihat partisipasi belajar siswa yang terjadi selama pembelajaran berlangsung. Hasil pengamatan observer terhadap partisipasi belajar siswa dalam pembelajaran dapat dilihat pada tabel berikut ini:

\section{Tabel 1}

Partisipasi Belajar Siswa Pada Siklus I

\begin{tabular}{ccccccc}
\hline Indikator & \multicolumn{5}{c}{ Pertemuan ke- } & Rata-rata persentase \\
\cline { 2 - 5 } & \multicolumn{2}{c}{1} & \multicolumn{2}{c}{2} & \\
& jumlah & $\%$ & jumlah & $\%$ & \\
$\mathbf{1}$ & 4 & $20 \%$ & 8 & $40 \%$ & $30 \%$ \\
$\mathbf{2}$ & 7 & $35 \%$ & 9 & $45 \%$ & $40 \%$ \\
$\mathbf{3}$ & 3 & $15 \%$ & 6 & $30 \%$ & $17.50 \%$ \\
\hline Jumlah siswa & 20 & & & 20 & \\
\hline
\end{tabular}

Keterangan:

1. Siswa mengemukakan pendapat

2. Siswa menjawab pertanyaan dari guru

3. Siswa mengajukan pertanyaan kepada guru

Berdasarkan data yang tertera pada tabel 1 di atas, dapat dikemukakan persentase partisipasi belajar siswa dalam pembelajaran PKN pada bagian yang diamati dan penjelasannya sebagai berikut:

a. Persentase rata-rata siswa mengemukakan pendapat adalah $30 \%$, berarti siswa masih malu-malu mengemukakan pendapat, walaupun belum terbiasa belajar dengan menggunakan Model Pembelajaran Guided Teaching.

b. Persentase rata-rata siswa menjawab pertanyaan adalah $40 \%$ berarti masih banyak dari siswa yang belum mampu untuk menjawab pertanyaan karena masih ragu-ragu untuk menjawab pertanyaan tersebut.

c. Persentase rata-rata siswa dalam mengajukan pertanyaan kepada guru adalah $17.50 \%$, berarti semua siswa belum dapat dikatakan baik dalam mengajukan pertanyaan kepada guru. 
2) Data Hasil Observasi Aktivitas Guru

Berdasarkan lembar observasi aktivitas guru dalam pembelajaran pada siklus I, maka jumlah skor dan persentase aktivitas guru dalam mengelola pembelajaran pada siklus I dapat dilihat pada tabel berikut ini:

Tabel 2

Aktivitas Guru Pada Siklus I

\begin{tabular}{c|ccc}
\hline Pertemuan & Jumlah Skor & Persentase & Keterangan \\
\hline I & 28 & $62,22 \%$ & Cukup \\
II & 32 & $71,11 \%$ & Baik \\
\multicolumn{2}{c}{ Rata-rata } & $66,66 \%$ & \\
\hline
\end{tabular}

Dari tabel 2 di atas, dapat dilihat analisis pada presentase guru dalam mengelola pembelajaran memiliki rata-rata persentase $66,66 \%$, sehingga sudah dapat dikatakan baik. Hal ini disebabkan karena guru belum melakukan keseluruhan indikator kegiatan guru yang telah ditetapkan dalam proses pembelajaran PKN.

3) Data Hasil Belajar

Berdasarkan hasil tes siklus I terkait Soal Tes persentase siswa yang tuntas dan rata-rata skor tesnya dapat dilihat pada tabel berikut:

Tabel 3

Ketuntasan dan Rata-rata Hasil Belajar Siswa pada Siklus I

\begin{tabular}{ccc}
\hline Uraian & Nilai & Target \\
\hline Jumlah siswa yang mengikuti tes & 20 & - \\
\hline Jumlah siswa yang tuntas tes & 9 & - \\
Jumlah siswa yang tidak tuntas tes & 11 & - \\
\hline Persentase ketuntasan tes & $45 \%$ & $70 \%$ \\
Rata-rata nilai tes & 59,68 & \\
\hline
\end{tabular}

Mencermati tabel 3 di atas, terlihat bahwa persentase ketuntasan hasil belajar siswa secara keseluruhan tergolong rendah yaitu 45\% dan rata-rata nilai tes belum mencapai KKM yang ditetapkan yaitu 70.

Dalam target ketuntasan belajar yang ditetapkan oleh peneliti pada indikator keberhasilan, ketuntasan belajar yaitu $70 \%$ dari jumlah siswa. Sedangkan ketercapaian ketuntasan hasil belajar siswa pada siklus I, belum mencapai target ketuntasan belajar (baru mencapai 45\%). Oleh karena itu peneliti ingin meningkatkannya pada siklus II untuk mencapai target ketuntasan belajar.

d) Tahap Refleksi

Kegiatan refleksi dilakukan antara peneliti dan kepala sekolah yang dilakukan pada setiap siklus berakhir. Refleksi siklus I ini mencakup refleksi terhadap perencanaan, pelaksanaan, evaluasi, dan hasil yang diperoleh oleh siswa. Dari tahap perencanaan, peneliti mempersiapkan RPP, lembar observasi partisipasi belajar siswa, aktivitas guru, tes hasil belajar. Dalam tahap ini, peneliti belum mempersiapkan perencanaan dengan maksimal. Dari pelaksanaan tindakan dan observasi pada siklus I ini, tampak bahwa rata-rata persentase partisipasi belajar siswa masih sedikit. Pada indicator partisipasi siswa mengemukakan pendapat masih sedikit yaitu 30\% sedangkan pada indicator partisipasi siswa menjawab pertanyaan dari guru yaitu $40 \%$ dan indikator partisipasi siswa dalam bertanya kepadada guru yaitu 17.50\%. Jadi, rata-rata persentase partisipasi belajar siswa siklus I masih dikatakan sedikit, belum mencapai target yang ditetapkan yaitu $70 \%$.

Berdasarkan temuan di atas, peneliti mengidentifikasi beberapa penyebab terjadinya masalah tersebut sebagai berikut:

1) Guru kurang memahami model Guided Teaching

2) Guru kurang memotivasi siswa dalam proses pembelajaran

3) Siswa belum terbiasa dengan model Guided Teachig

4) Siswa masih malu-malu untuk menjawab pertanyaan dari guru

5) Siswa masih banyak bermain pada saat temannya membacakan jawaban, sehingga tidak dapat mengemukakan pendapat dan bertanya

Permasalahan di atas berdampak pada kurang maksimalnya hasil belajar dan peneliti memutuskan untuk melanjutkan penelitian pada siklus II. Adapun yang dapat dilakukan guru untuk meningkatkan partisipasi belajar siswa pada siklus II adalah:

1) Guru harus lebih memahami model Guided Teaching

2) Guru harus memotivasi siswa, agar siswa berpartisipasi dalam proses pembelajaran 
3) Guru meminta kepada siswa untuk belajar dirumah, supaya tidak malu-malu untuk memjawab pertanyaan

4) Guru lebih memperhatikan siswa yang mengemukkan pendapat dan bertanya, dan menyakini siswa agar tidak takut salah.

\section{Siklus II}

a) Tahap Perencanaan

Dari hasil refleksi siklus I diperoleh kesimpulan bahwa pembelajaran belum berjalan dengan efektif. Hal ini disebabkan oleh beberapa kelemahan dalam pelaksanaan pembelajaran PKN melalui model Guided Teaching. Permasalahan terjadi karena siswa belum terbiasa dengan menggunakan model pembelajaran Guided Teaching, sehingga terdapat beberapa siswa yang belum melakukan indikator keberhasilan yang ingin dicapai pada saat pembelajaran. Dalam menyajikan pembelajaran peneliti belum efektif sehingga membuat partisipasi belajar siswa dalam mengemukakan pendapat, menjawab pertanyaan dari guru dan partisipasi bertanya kepada guru masih dikategorikan sedikit. Berdasarkan hasil ini direncanakan perbaikan terhadap tindakan yang akan diterapkan pada siklus II, yaitu:

1) Pada indikator partisipasi siswa dalam mengemukakan pendapat, rata-rata persentase siklus I yaitu 30 $\%$,

sementara itu target yang akan dicapai adalah 75\%. Oleh karena itu, peneliti melakukan tindakan dengan meminta siswa untuk membaca pelajaran di rumah, sehingga pada pertemuan selanjutnya siswa mau untuk mengemukakan kepada guru.

2) Pada indikator partisipasi siswa menjawab pertanyaan dari guru, rata-rata persentase siklus I yaitu $40 \%$, sementara itu target yang akan dicapai adalah $72 \%$. Oleh karena itu, peneliti melakukan tindakan dengan meminta siswa untuk membaca pelajaran di rumah, sehingga pada pertemuan selanjutnya siswa mampu menjawab pertanyaan pada soal latihan.

3) Pada indikator partisipasi siswa bertanya kepada guru, rata-rata persentase siklus I yaitu $17.50 \%$, sementara itu target yang akan dicapai adalah 70\%. Oleh karna itu, peneliti melakukan tindakan dengan lebih memperhatikan siswa yang akan bertanya dan meyakinkan siswa agar tidak takut salah.

Selanjutnya untuk memulai pembelajaran, terlebih dahulu peneliti menyiapkan rencana pelaksanaan pembelajaran RPP, lembar observasi partisipasi belajar siswa, lembar observasi aktivitas guru dan lembar jawaban siswa. Pada siklus II ini peneliti melaksanakan dua kali pertemuan. Pada pertemuan ketiga diadakan tes akhir siklus II.

\section{b) Tahap Pelaksanaan}

Sama dengan pelaksanaan siklus I, proses pelaksanaan siklus II terbagi menjadi dua kali pertemuan. Proses pembelajaran dibagi menjadi tiga, yaitu kegiatan awal, kegiatan inti, kegiatan akhir.

\section{c) Tahap Pengamatan}

Pengamatan dilakukan untuk setiap kali pertemuan oleh observer dan observer mengisi lembar observasi partisipasi belajar siswa, lembar observasi aktivitas guru dan lembaran tes hasil belajar. Dalam pembelajaran IPS melalui model Pembelajaran Guided Teaching, pada akhir siklus diberikan tes hasil belajar berupa soal tes. Hasil pengamatan observer penelitian terhadap aktivitas pembelajaran menunjukkan bahwa pembelajaran yang peneliti laksanakan sudah berlangsung dengan sangat baik dan dirasa pelaksanaan pembelajaran sudah maksimal yaitu terlihat pada partisipasi belajar siswa, aktivitas guru dan tes hasil belajar berupa soal tes. Untuk lebih jelasnya, hasil observasi observer peneliti terhadap partisipasi belajar siswa, aktivitas guru dan tes siswa diuraikan sebagai berikut:

1) Data Hasil Observasi Partisipasi Belajar Siswa

Data hasil observasi ini didapat melalui lembar observasi partisipasi belajar siswa, dan digunakan untuk melihat partisipasi belajar siswa yang terjadi selama pembelajaran berlangsung. Hasil pengamatan observer terhadap partisipasi belajar siswa dalam pembelajaran dapat dilihat pada tabel berikut ini 


\section{Tabel 4}

Partisipasi Belajar Siswa Pada Siklus II

\begin{tabular}{cccc|c|c}
\hline Indikator & \multicolumn{4}{c}{ Pertemuan Ke } & \multirow{2}{*}{ Rata-rata Persentase } \\
\cline { 2 - 5 } & \multicolumn{2}{c}{1} & \multicolumn{2}{c}{2} & \\
& Jumlah & $\%$ & Jumlah & $\%$ & \\
I & 14 & $70 \%$ & 17 & $85 \%$ & $77.5 \%$ \\
II & 16 & $80 \%$ & 18 & $90 \%$ & $85 \%$ \\
III & 12 & $60 \%$ & 16 & $80 \%$ & $70 \%$ \\
\hline Jumlah Siswa & \multicolumn{2}{c|}{20} & \multicolumn{2}{c}{20} & \\
\hline
\end{tabular}

Keterangan:
Indikator I
: Partisipasi siswa mengemukakan pendapat
Indikator II
: Partisipasi siswa menjawab pertanyaan
Indikator III
: Partisipasi siswa bertanya kepada guru

Berdasarkan tabel 4 di atas, dapat disimpulkan bahwa pada siklus II ini partisipasi belajar siswa sesuai dengan indikator yang ditetapkan. Dari tabel jumlah dan persentase partisipasi belajar siswa siklus II di atas terlihat partisipasi belajar siswa dalam rata-rata dari indikator siswa mengemukakan pendapat, indikator menjawab pertanyaan dari guru, indikator bertanya sudah melebihi target peningkatan yaitu $>70 \%$.

2) Data Hasil Observasi Aktivitas Guru

Berdasarkan lembar observasi aktivitas guru dalam pembelajaran pada siklus II, maka jumlah skor dan persentase aktivitas guru dalam mengelola pembelajaran pada siklus II dapat dilihat pada tabel berikut ini:

Tabel 5

Aktivitas Guru Pada Siklus II

\begin{tabular}{cccc}
\hline Pertemuan & Jumlah Skor & Persentase & Keterangan \\
\hline I & 36 & $80 \%$ & Sangat Baik \\
II & 38 & $84,44 \%$ & Sangat Baik \\
\multicolumn{2}{c}{ Rata-rata } & $82,22 \%$ & \\
\hline
\end{tabular}

Dari tabel 5 di atas, dapat dilihat analisis pada presentase guru dalam mengelola pembelajaran memiliki rata-rata persentase $82,22 \%$, sehingga sudah dikatakan sangat baik. Hal ini disebabkan karena guru sudah melakukan keseluruhan indikator aktivitas guru yang telah ditetapkan dalam proses pembelajaran PKN.

3) Data Hasil Belajar pada tes

Berdasarkan hasil tes siklus II terkait soal tes, persentase siswa yang tuntas tes dan rata-rata skor tesnya dapat dilihat pada tabel berikut:

Tabel 6

Ketuntasan dan Rata-rata Hasil Belajar Siswa pada Siklus II

\begin{tabular}{lll}
\hline Uraian & Nilai & Target \\
\hline Jumlah siswa yang mengikuti tes & 20 & - \\
Jumlah siswa yang tuntas tes & 18 & - \\
Jumlah siswa yang tidak tuntas tes & 2 & - \\
Persentase ketuntasan tes & $90 \%$ & $70 \%$ \\
Rata-rata nilai tes & 77.5 & 70 \\
\hline
\end{tabular}

Berdasarkan tabel 6 di atas dapat dilihat hasil tes belajar siswa pada siklus II sudah mencapai KKM yang ditetapkan sekolah. KKM yang ditetapkan oleh sekolah adalah $\geq 70$, sementara nilai rata-rata yang diperoleh siswa adalah $77.5 \%$. Jumlah siswa yang mendapat nilai $\geq 70$ sebanyak 18 siswa dan yang mendapat nilai di bawah 70 adalah 2 siswa dari 20 siswa.

d) Tahap Refleksi

Hasil diskusi peneliti dengan observer bertujuan untuk mendapatkan gambaran tentang pelaksanaan tindakan pada siklus II. Berdasarkan gambaran yang diperoleh, tampak bahwa rata-rata persentase partisipasi belajar siswa untuk masing-masing indikator sudah mencapai target yaitu $>70 \%$. Dari tahap perencanaan, peneliti telah mempersiapkan dengan sebaik-baiknya RPP, lembar observasi partisipasi belajar siswa, lembar 
observasi aktivitas guru. Peneliti telah merencanakan pelaksanaan tindakan sesuai dengan langkah-langkah pembelajaran model pembelajaran Guided Teaching dan peneliti telah mempersiapkan tes hasil belajar siswa siklus II.

Dari pelaksanaan tindakan, guru telah melaksanakan pembelajaran sesuai dengan langkah-langkah model pembelajaran Guided Teaching. Berdasarkan observasi observer terhadap partisipasi belajar siswa dari siklus I ke siklus II, rata-rata persentase partisipasi belajar siswa sudah mencapai target sehingga dapat dikatakan meningkat. Untuk data observasi kegiatan guru dalam mengelola pembelajaran sudah mengalami peningkatan dibandingkan siklus sebelumnya, dan juga sudah dikatakan baik.

\section{B. Pembahasan}

Penelitian tindakan kelas ini terdiri dari dua siklus yang setiap siklusnya terdiri dari 2 kali pertemuan dan 1 kali tes hasil belajar pada akhir siklus. Pelaksanaan pembelajaran yang dilaksanakan menggunakan model pembelajaran Guided Teaching. Penelitian ini menggunakan instrumen penelitian berupa lembar observasi partisipasi belajar siswa, lembar observasi aktivitas guru serta tes hasil belajar. Melalui model pembelajaran Guided Teaching merupakan hal yang baru bagi siswa sehingga dalam pelaksanaannya peneliti menemui berbagai kendala. Berdasarkan gambaran serta penjelasan tentang model pembelajaran Guided Teaching di atas, peneliti memulai penelitian dengan merancang beberapa tahapan, dimulai perencanaan yaitu mengkaji silabus mata pelajaran PKN kelas VI semester ganjil, kemudian peneliti menyiapkan perangkat pembelajaran (RPP).

Selanjutnya, peneliti memilih buku pegangan yaitu buku paket Pendidikan Kewargaan Negara penerbit Erlangga untuk SD kelas VI. Lalu, peneliti menyiapkan media pembelajaran, menyusun lembar observasi partisipasi belajar siswa, menyusun lembar observasi aktivitas guru dan menyusun tes hasil belajar siswa. Selanjutnya, pada proses pelaksanaan pembelajaran yang dimulai dari kegiatan awal berisi berdo'a, apersepsi dan motivasi, kegiatan inti berisi menyampaikan materi pelajaran, pembelajaran menggunakan model pembelajaran Guided Teaching, dan cara guru dalam melaksanakan proses pembelajaran yaitu eksplorasi, elaborasi, dan konfirmasi. Kemudian, pada kegiatan akhir pembelajaran, berisi evaluasi dan untuk memperkuat data kejelasan peningkatan tersebut maka diadakan tes hasil belajar, di sini peneliti gunakan adalah berupa soal tes. Untuk lebih rincinya dapat dilihat pada penjelasan dibawah ini:

\section{Aktivitas Guru Dalam Proses Pembelajaran}

Keberhasilan siswa dalam pembelajaran pada umumnya dilihat juga dari pengelolaan pelaksanaan pembelajaran pada persentase aktivitas guru. Dalam hal ini terlihat peningkatan pengelolaan pelaksanaan pembelajaran melalui model pembelajaran Guided Teaching pada tabel di bawah ini:

\section{Tabel 7}

Perbandingan Aktivitas Guru Pada Siklus I dan Siklus II

\begin{tabular}{|c|c|c|c|c|}
\hline \multirow[t]{2}{*}{$\overline{\text { No. }}$} & \multirow[t]{2}{*}{ Aspek yang Dinilai } & \multicolumn{2}{|c|}{ Perbandingan Aktivitas Guru } & \multirow[t]{2}{*}{ Peningkatan } \\
\hline & & Siklus I & Siklus II & \\
\hline 1 & Aktivitas guru & $66,66 \%$ & $82,22 \%$ & $15,56 \%$ \\
\hline
\end{tabular}

Dari tabel 7 di atas, pelaksanaan pembelajaran melalui model pembelajaran Guided Teaching dapat dideskripsikan sebagai berikut.

1. Hasil pengamatan terhadap aktivitas guru, terlihat adanya peningkatan sebesar $15,56 \%$, dari $66,66 \%$ pada siklus I menjadi $82,22 \%$ pada siklus II.

2. Tantangan yang dihadapi guru selama proses pembelajaran salah satunya adalah guru belum terbiasa menggunakan model pembelajaran Guided Teaching.

\section{Partisipasi Siswa Dalam Proses Pembelajaran}

Partisipasi siswa dalam belajar adalah hal yang paling utama dalam pembelajaran. Partisipasi juga memiliki peranan sangat penting untuk mencapai keberhasilan dalam belajar, karena dengan adanya partisipasi belajar, siswa dapat melakukan sesuatu hal secara tekun dan disiplin, untuk mencapai hasil belajar yang baik. Dengan meningkatnya partisipasi belajar dalam pembelajaran PKN dari seorang siswa, diharapkan juga dapat meningkatkan hasil belajar dalam pembelajaran PKN. Dalam penelitian ini, indikator Partisipasi belajar yang diukur dengan menggunakan model pembelajaran Guided Teaching adalah partisipasi siswa dalam mengemukakan pendapat, partisipasi siswa menjawab pertanyaan serta partisipasi siswa mengajukan pertanyaan kepada guru. Untuk lebih jelasnya, dapat dilihat pada tabel di bawah ini: 


\section{Tabel 8}

Persentase Rata-rata Partisipasi Belajar Siswa pada Siklus I dan Siklus II

\begin{tabular}{llll}
\hline No. & Indikator Partisipasi Belajar Siswa & \multicolumn{2}{c}{ Rata-rata Persentase } \\
\cline { 3 - 4 } & & Siklus I & Siklus II \\
1. & Siswa mengemukakan pendapat & $30 \%$ & $77.5 \%$ \\
2. & Siswa menjawab pertanyaan & $40 \%$ & $85 \%$ \\
3. & Siswa mengejukan pertanyaan kepada guru & $17.5 \%$ & $70 \%$ \\
\hline
\end{tabular}

Berdasarkan tabel 8 di atas, dapat disimpulkan bahwa pembelajaran PKN melalui model pembelajaran Guided Teaching yang dilaksanakan dapat meningkatkan partisipasi belajar siswa. Hal ini terbukti dari kenaikan rata-rata persentase untuk masing-masing indikator keberhasilan partisipasi belajar siswa yang telah ditetapkan. Partisipasi belajar siswa untuk indikator siswa mengemukakan pendapat pada siklus I adalah 30 $\%$. Hal ini belum mencapai target yaitu $75 \%$, sehingga pada siklus II guru melakukan tindakan dengan meminta siswa untuk membaca pelajaran di rumah dan menyemangati siswa yang malu mengemukakan pendapat, sehingga pada pertemuan selanjutnya siswa mau untuk bertanya kepada guru yang belum dipahaminya. Hal ini dapat meningkatkan partisipasi belajar siswa dalam mengemukakan pendapat pada siklus II yaitu $77.5 \%$ dan telah melebihi dari target yang ditentukan yaitu $75 \%$.

Pada indikator menjawab pertanyaan, terlihat rata-rata persentase yang diperoleh siswa pada siklus I adalah $40 \%$. Hal ini belum mencapai target yang ditetapkan yaitu $72 \%$. Oleh karena itu, pada siklus II, guru berusaha meningkatkannya dengan cara meminta siswa untuk membaca pelajaran di rumah, sehingga pada pertemuan selanjutnya siswa mampu menjawab pertanyaan pada soal latihan. Hal ini mampu meningkatkan partisipasi belajar siswa dalam menjawab pertanyaan pada siklus II yaitu $85 \%$. Pada indikator siswa mengajukan pertanyaan kepada guru, rata-rata persentase partisipasi belajar siswa pada siklus I adalah $17.5 \%$. Hal ini belum mencapai target yang ditetapkan yaitu $70 \%$. Oleh karena itu pada siklus II, guru berusaha meningkatkannya dengan cara lebih memperhatikan siswa yang akan bertanya dan memotivasi agar tidak takut salah dalam bertanya. Hal ini mampu meningkatkan rata-rata persentase partisipasi belajar siswa berdiskusi pada siklus II yaitu $70 \%$ dan sudah mencapai target yang ditetapkan yaitu $70 \%$.

Berdasarkan penjelasan di atas dapat disimpulkan bahwa pada pelaksanaan pembelajaran PKN melalui model pembelajaran Guided Teaching dapat terjadi peningkatan partisipasi belajar siswa. Hal ini terbukti dari kenaikan rata-rata persentase untuk masing-masing indikator keberhasilan partisipasi belajar siswa yang telah ditetapkan.

\section{Hasil Belajar}

Berdasarkan hasil ulangan siswa yang dilakukan pada setiap akhir siklus, hasil belajar siswa mengalami peningkatan yang cukup baik. Peningkatan ini terlihat dari nilai rata-rata kelas yang meningkat pada setiap siklusnya. Peningkatan tersebut dapat dilihat pada tabel 9 berikut ini.

\section{Tabel 9}

Perbandingan Persentase Hasil Belajar Siswa Pada Siklus I dan Siklus II

\begin{tabular}{ccc}
\hline Perbandingan Hasil Belajar Siswa & Peningkatan \\
\hline Siklus I & Siklus II & 48.33 \\
$\mathbf{2 9 . 1 7}$ & 77.5 & \\
\hline
\end{tabular}

Berdasarkan tabel 9 di atas terjadi peningkatan sebesar $48.33 \%$ pada persentase ketuntasan tes hasil belajar siswa, yakni dari $27.17 \%$ pada siklus I meningkat menjadi $77.5 \%$ pada siklus II.

Dari penjabaran hasil penelitian dan pembahasan di atas, maka dapat kita simpulkan bahwa model guided teaching dapat meningkatkan partisipasi siswa dalam belajar. Hal ini sejalan dengan pendapat Istarani (2012:227) tentang kelebihan model pembelajaran Guided Teaching, yaitu: (1) dapat meningkatkan motivasi belajar siswa sebab pembelajaran diawali dengan pertanyaan; (2) melatih siswa berfikir untuk menjawab pertanyaan secara benar; dan (3) dapat meningkatkan kerjasama siswa karena dalam belajara dibentuk kelompok-kelompok kecil.

\section{KESIMPULAN DAN SARAN \\ KESIMPULAN}

Berdasarkan hasil penelitian dan pembahasan yang telah dipaparkan sebelumnya, maka peneliti menyimpulkan hal-hal sebagai berikut. 
1. Partisipasi siswa dalam mengemukakan pendapat kepada guru pada pembelajaran PKN kelas VI SD Negeri 17 Batang Anai cenderung dapat ditingkatkan melalui model pembelajaran Guided Teaching. Kesimpulan ini terbukti dari hasil rata-rata persentase partisipasi siswa pada siklus I untuk indikator 1 siswa mengemukakan pendapat yaitu 30\%, dan siklus II untuk siswa mengemukakan pendapat yaitu 77.5\%. Sehingga terdapat peningkatan $47.5 \%$.

2. Partisipasi siswa menjawab pertanyaan dari guru pada pembelajaran PKN kelas VI SD Negeri 17 Batang Anai cenderung dapat ditingkatkan melalui model pembelajaran Guided Teaching. Kesimpulan ini terbukti dari hasil rata-rata persentase partisipasi siswa pada siklus I untuk indikator 2 siswa menjawab pertanyaan dari guru yaitu $40 \%$, dan siklus II untuk menjawab pertanyaan dari guru yaitu $85 \%$. Sehingga terdapat peningkatan $45 \%$.

3. Partisipasi siswa mengajukan pertanyaan kepada guru pada pembelajaran PKN kelas VI SD Negeri 17 Batang Anai cenderung dapat ditingkatkan melalui model pembelajan Guided Teaching. Kesimpulan ini terbukti dari hasil rata-rata persentase partisipasi siswa pada siklus I indikator 3 siswa mengajukan pertanyaan kepada guru yaitu $17.5 \%$, dan siklus II mengajukan pertanyaan kepada guru yaitu $70 \%$. Sehingga terdapat peningkatan $52.5 \%$.

\section{SARAN}

Berdasarkan kesimpulan yang telah dicantumkan di atas, maka peneliti mengajukan beberapa saran untuk dipertimbangkan:

1. Menyarankan agar guru memberikan ingatan yang kuat kepada siswa agar bisa meningkatkan pemahaman tentang azas pemilu sehingga siswa tidak malu-malu untuk berpartisipasi mengemukakan pendapat disaat proses pembelajaran PKN.

2. Menyarankan agar guru memberikan hadiah kepada siswa yang berpartisipasi sehingga siswa bersemangat untuk berpartisipasi dalam menjawab pertanyaan dari guru di saat proses pembelajaran PKN.

3. Menyarankan agar guru memotivasi dan memberi semangat kepada siswa sehingga siswa tidak takut untuk bertanya kepada guru di saat proses pembelajaran.

\section{DAFTAR PUSTAKA}

Arikunto, Suharsimi, dkk. 2010. Penelitian Tindakan Kelas. Jakarta: Bumi Aksara Depdiknas. 2006. Kurikulum Tingkat Satuan Pendidikan. Jakarta: BNSP

Istarani, 2012. 58 Model Pembelajaran Inovatif. Medan: Media Persada

Kunandar, 2008. Langkah Mudah Penelitian Tindakan Kleas Sebagai Pengembangan Profesi Guru. Jakarta: Rajawali Pers

Mulyasa, E. 2006. Kurikulum yang Disempurnakan: Pengembangan Standar Kompetensi dan Kompetensi Dasar. Bandung: Remaja Rosda Karya

Ruminiati. 2007. Pengembangan Pendidikan Kewarganegaraan SD. Jakarta: Dirjen Dikti Depdiknas

Sapriya, dkk. 2006. Pembelajaran dan evaluasi hasil belajar IPS. Bandung: UPI Press

Silberman, Mel. 2009. Active Learning 101 Strategi Pembelajaran Aktif. Yogyakarta: Pustaka Insani Madani

Slameto. 2010. Belajar dan Faktor-faktor yang Mempengaruhinya. Jakarta: Rineka Cipta

Suharsimi, 2009. Kriteria Hasil Belajar. Jakarta: Rajawali Pers

Suprijono, 2010. Cooperative Learning Teori dan Aplikasi Paikem. Yogyakarta: Pustaka Belajar Susanto, Ahmad, 2013. Teori Belajar dan Pembelajaran di Sekolah Dasar. Jakarta: Prenada Media

Taniredja, Tukiran, dkk. 2010. Penelitian Tindakan Kelas Untuk Pembangunan Profesi Guru. Bandung: Alfabeta

Taufik, Taufina dan Muhammadi. 2011. Mozaik Pembelajaran Inovatif. Jakarta: Sukabina Press 